\title{
Empowerment of peer group in prevention of drug abuse
}

\author{
Vita Camellia $^{1 *}$, Mastauli Siregar ${ }^{2}$ \\ ${ }^{1)}$ Department of Mental Health, Faculty of Medicine, Universitas Sumatera Utara \\ ${ }^{2)}$ Department of Social Welfare Studies, Faculty of Social and Political Sciences, Universitas \\ Sumatera Utara \\ *Email: camelliavita@yahoo.com
}

\begin{abstract}
Hutauruk Village in Sipoholon Subdistrict is one of the tourist destination locations in North Tapanuli, which is a hot spring which is very crowded with tourists from outside Taput. with a very high rate of drug abuse. Due to the large number of outsiders coming this allows the rampant drug abuse that occurred in the village of Hutauruk due to the influence of outside culture that entered the village. Drug abuse is carried out by teenagers, adults and parents. In this village there are many groups of teenagers who use drugs. In the mechanism of substance abuse, peer groups (peer groups) have an influence that can encourage or trigger drug abuse in a person. Peers have an influence on the consumption behavior of substances such as tobacco, alcohol, and other drugs. Peer is an external factor that can also influence adolescence, both positive and negative promiscuity. This service was carried out in Hutauruk Village, Sipoholon District, North Tapanuli Regency. The output target of this service is partners understanding the importance of healthy living without drugs, being able to build self-confidence, being able to manage a doormeer business, building a doormeer business that fills in leisure time and a new source of income for partners because it brings economic value.
\end{abstract}

Key words : Drugs, Teens, Peers, Doorsmeer Enterprises

\begin{abstract}
Abstrak
Desa Hutauruk di Kecamatan Sipoholon merupakan salah satu lokasi tujuan wisata di Tapanuli Utara yakni pemandian air panas (hot spring) yang sangat ramai dikunjungi orang wisatawan dari luar Taput. dengan tingkat penyalahgunaan narkoba yang sangat tinggi. Karena banyaknya orang luar yang datang hal ini memungkinkan maraknya penyalahgunaan narkoba yang terjadi di Desa Hutauruk yang disebabkan pengaruh budaya luar yang masuk ke desa. Penyalahgunaan narkoba dilakukan oleh remaja, dewasa maupun orang tua. Di desa ini terdapat banyak kumpulan remaja yang menggunakan narkoba. Dalam mekanisme terjadinya penyalahgunaan zat, teman kelompok sebaya (peer group) mempunyai pengaruh yang dapat mendorong atau mencetuskan penyalahgunaan narkoba pada diri seseorang. Teman sebaya memiliki pengaruh terhadap perilaku konsumsi zat-zat seperti tembakau, alkohol, dan obat-obatan lainnya. Teman sebaya merupakan faktor eksternal yang juga dapat memengaruhi pergaulan pada remaja, baik itu pergaulan yang positif maupun pergaulan yang negatif. Pengabdian ini dilaksanakan di Desa Hutauruk, Kecamatan Sipoholon, Kabupaten Tapanuli Utara. Target luaran dari pengabdian ini adalah mitra memahami arti penting hidup sehat tanpa narkoba, mampu membangun rasa percaya dirinya, mampu mengelola usaha doorsmeer, terbangunnya usaha doorsmeer yang menjadi pengisi waktu senggang dan sumber pendapatan baru bagi mitra karena mendatangkan nilai ekonomi.
\end{abstract}

Kata kunci : Narkoba, Remaja, Teman Sebaya, Usaha Doorsmeer

\section{PENDAHULUAN}

Desa Hutauruk di Kecamatan Sipoholon merupakan salah satu lokasi tujuan wisata di Tapanuli Utara yakni pemandian air panas (hot spring) yang sangat ramai dikunjungi orang wisatawan dari luar Taput. dengan tingkat penyalahgunaan narkoba yang sangat tinggi. Karena banyaknya orang luar yang datang hal ini memungkinkan maraknya penyalahgunaan narkoba yang terjadi di Desa Hutauruk yang disebabkan pengaruh budaya luar yang masuk ke desa. Penyalahgunaan narkoba 
dilakukan oleh remaja, dewasa maupun orang tua. Di desa ini terdapat banyak kumpulan remaja yang menggunakan narkoba.

Untuk itu guna mencegah kelompok remaja ini masuk dalam penyalahgunaan narkoba maka perlu untuk mengisi waktu mereka dengan hal-hal yang positif dan bermanfaat.

Teman sebaya mempunyai pengaruh besar bagi anak-anak remaja, mereka merasa dekat satu sama lain dan biasanya sudah membentuk kelompok (geng), mereka mempunyai rasa senasib dan sepenanggungan, rasa solidaritas tiggi. Dengan demikian, mereka akan dengan mudahnya melakukan hal-hal yang dianggap menyenangkan oleh kelompoknya. Mereka tidak memikirkan baik buruknya, tetapi memikirkan apa itu menyenangkan atau tidak. Juga tidak mempertimbangkan akan adanya resiko-resiko bagi dirinya. Bahkan, untuk memenuhi keinginannya agar diterima kelompoknya, mereka tidak segan-segan melakukan hal-hal yang sebenarnya disadari merupakan perbuatan yang tidak baik.

Hawari dalam penelitiannya menyebutkan bahwa 81,3\% seseorang yang menggunakan narkoba diawali oleh pengaruh/bujukan teman (peer group). Penolakan atau tekanan dari kelompok/ teman sebaya mengakibatkan remaja merasa dikucilkan, oleh karena itu tidak mudah bagi remaja untuk meninggalkan kelompok. Meninggalkan kelompok bagi remaja berarti kehilangan teman serta sebagian hidupnya (Sally, 2012).

Dalam mekanisme terjadinya penyalahgunaan zat, teman kelompok sebaya (peer group) mempunyai pengaruh yang dapat mendorong atau mencetuskan penyalahgunaan narkoba pada diri seseorang. Pada banyak kasus, perkenalan pertama dengan narkoba biasanya datang dari teman sebaya.

Teman sebaya memiliki pengaruh terhadap perilaku konsumsi zat-zat seperti tembakau, alkohol, dan obat-obatan lainnya. Teman sebaya merupakan faktor eksternal yang juga dapat memengaruhi pergaulan pada remaja, baik itu pergaulan yang positif maupun pergaulan yang negative. Pergaulan positif seperti kelompok belajar, dan keikutsertaan dalam kegiatan ekstrakurikuler yang bermanfaat. Sedangkan pergaulan negatif adalah yang berhubungan dengan kenakalan remaja, seperti pengkonsumsian narkotika, alkohol, psikotropika, dan zat adiktif (napza) yang pada saat ini sudah banyak.

Melihat analisis situasi tersebut membuat tim pengusul merasa perlu unutk melakukan pengabdian pada masyarakat ini dengan judul "Pemberdayaan Kelompok Teman Sebaya (Peer Group) Dalam Pencegahan Penyalahgunaan Narkoba".

\subsection{Permasalahan Mitra}

Berdasarkan analisis situasi di atas, maka permasalahan mitra dalam pengabdian masyarakat ini adalah :

1. Rendahnya pengetahuan kelompok mitra mengenai arti penting hidup sehat tanpa narkoba.

2. Rendahnya pengetahuan dan keterampilan kelompok mitra dalam cara mengelola dan mengembangkan usaha doorsmeer.

3. Minimnya modal usaha kelompok mitra untuk dapat membangun dan menjalankan usaha doorsmeer sebagai upaya mengisi waktu luang sekaligus memperoleh pendapatan.

4. Rendahnya pengetahuan kelompok mitra dalam pengelolaan usaha doorsmeer yang profesional dan memberikan kepuasan kepada pelanggan untuk mendatangkan keuntungan ekonomi, sehingga mampu meningkatkan pendapatan secara signifikan.

\subsection{Solusi Yang Ditawarkan}

Berdasarkan permasalahan yang ditetapkan di atas maka solusi yang ditawarkan dalam pengabdian masyarakat ini adalah :

1. Diskusi, menjelaskan dan meyakinkan mitra tentang pentingnya hidup sehat tanpa narkoba.

2. Melaksanakan penyuluhan untuk membangkitkan rasa percaya diri mitra.

3. Melaksanakan pelatihan cara mengelola doorsmeer dan membangun kepercayaan pelanggan.

4. Membimbing mitra menjalankan manajemen usaha doorsmeer sehingga mampu menghitung laba dan menganalisis biaya yang baik, yang bermuara pada peningkatan pendapatan.

5. Membangun usaha doorsmeer.

\subsection{Target Luaran}

Adapun luaran dari pengabdian ini adalah :

1. Mitra memahami arti penting hidup sehat tanpa narkoba. 
2. Mitra mampu membangun rasa percaya dirinya.

3. Mitra mampu mengelola usaha doorsmeer dan membangun kepercayaan pelanggan.

4. Terbangunnya usaha doorsmeer dan terciptanya wirausahawan doorsmeer.

5. Menjadi pengisi waktu senggang dan sumber pendapatan baru bagi mitra karena mendatangkan nilai ekonomi.

\section{METODE PELAKSANAAN}

\subsection{Metode Pendekatan}

Metode pendekatan yang dilakukan selama melakukan pengabdian kepada mitra adalah dengan cara diskusi, penyuluhan, pelatihan, bimbingan dan pendampingan. Pengukuran perubahan terhadap perilaku mitra dapat dilihat dari perilaku mitra yang berubah menjadi terbiasa dan bersemangat serta memiliki rasa percaya diri. Mitra menjadi mengetahui teknik berwirausaha doorsmeer. Melalui kegiatan pengabdian ini mitra juga diharapkan semakin memiliki mental kewirausahaan serta mampu meningkatkan produksi dan produktivitasnya setelah diberikan pelatihan.

\subsection{Rencana Kegiatan}

Rencana kegiatan yang akan dilakukan untuk pemecahan masalah adalah dengan tahapan sebagai berikut :

a. Diskusi

Dilakukan oleh tim pengabdian tentang rencana kegiatan. Berdasarkan diskusi ini tim pengabdian akan dapat mengetahui ketertarikan masyarakat terhadap kegiatan pengabdian. Selain itu dapat membangun motivasi tinggi untuk meningkatkan keterampilan usaha.

b. Penyuluhan

Dilakukan oleh tim pengusul untuk menjelaskan pentingnya hidup sehat tanpa narkoba. Tanpa narkoba, rasa percaya diri dan optimisme untuk menjalani hidup lebih baik akan terbangun.

c. Pelatihan dan pembangunan usaha doorsmeer

Pelatihan dimulai dengan pembangunan usaha doorsmeer. Hal ini dilakukan karena diyakini bahwa pelatihan usaha doorsmeer akan lebih efektif jika disertai dengan membangun fasilitas yang dibutuhkan dalam usaha doorsmeer. Pelatihan dilakukan dengan mengundang pakar yang memang sudah berpengalaman dalam membuat dan menjalankan usaha doorsmeer. Dalam pelatihan ini maka tim pengabdian akan memfasillitasi dan menyediakan semua bahan-bahan dan peralatan yang diperlukan dalam usaha doorsmeer.

d. Bimbingan

Dalam pelatihan ini tim pengabdian akan mengajarkan bagaimana cara membangun kepercayaan pelanggan. Selain itu juga memberi pelatihan agar memiliki mental kewirausahaan serta mampu dan percaya diri dalam mengembangkan usaha doorsmeer.

e. Evaluasi

Evaluasi akan dilakukan selama pelaksanaan kegiatan pengabdian yang meliputi pengamatan keterampilan dalam usaha doorsmeer dan pengamatan dalam strategi pemasaran. Selain itu juga evaluasi akan dilakukan meskipun kegiatan pelatihan sudah selesai, yaitu dengan bertelepon menanyakan kemajuan usaha doorsmeer selama ini dan juga dengan mengunjungi kembali pengusaha doorsmeer serta menanyakan keuntungan dan hambatan yang dijumpai setelah kegiatan pelatihan selesai dilakukan.

\subsection{Kontribusi Partisipasi Mitra}

Dalam pelaksanaan pengabdian ini mitra pengabdian diharapkan memberikan kontribusi sebagai berikut :

1. Mitra bersedia mengikuti segala bentuk penyuluhan dan pelatihan. Berniat untuk merubah pola hidup menjadi lebih sehat.

2. Mitra akan diminta supaya berkomitmen menghindari peredaran negatif dan penyalahgunaan narkoba.

3. Mitra akan diminta supaya aktif dan berkomitmen untuk menjalankan usaha doorsmeer sesuai dengan yang dianjurkan. 
4. Mitra bersedia mengikuti pelatihan strategi dalam pemasaran yang akan dipraktekkan oleh mitra untuk menjamin keberhasilan usaha mereka.

5. Mitra bersedia menerapkan apa yang telah diajarkan pada pelatihan dan bersedia dievaluasi.

6. Mitra bersedia juga mengikuti pelatihan dalam menghitung total pendapatan, mengetahui faktor-faktor yang menentukan besarnya pendapatan penjualan.

7. Mitra mampu menghitung total biaya dan mengetahui cara untuk meminimalkan biaya produksi serta mampu menghitung keuntungan per bulan.

8. Mitra bersedia dan diteguhkan untuk membangun karakter kewirausahaan.

\section{HASIL DAN PEMBAHASAN}

Sipoholon merupakan salah satu daerah yang strategis di dalam pengedaran dan penyalahgunaan narkoba karena merupakan tempat berwisata bagi pengunjung lokal maupun mancanegara. Hal ini memungkinkan maraknya penyalahgunaan narkoba yang terjadi di Sipoholon. Penyalahgunaan narkoba dilakukan oleh remaja, dewasa maupun orang tua. Di desa ini terdapat banyak perkumpulan orang-orang yang menggunakan narkoba. Sebagai bukti di desa Hutauruk banyak diadakan penangkapan bandar narkoba oleh pihak BNNK Taput maupun pihak kepolisian. Kasus penyalahgunaan narkoba di Desa Hutauruk sudah menjadi masalah sejak dulu, bahkan belum dapat di selesaikan sampai saat ini.

Di desa Hutauruk ini juga banyak kelompok teman sepermainan atau dapat dikatakan kelompok teman sebaya yang setiap pulang sekolah mereka akan berkumpul (nongkrong) disebuah warung dan pada waktu sore hari berkumpul di lapangan untuk bermain sepak bola atau permainan lainnya. Desa ini juga memiliki pemuda-pemudi yang aktif dalam organisasi keagamaan misalnya pemuda-pemudi (naposo bulung) gereja HKBP, GKPI, Katolik dan gereja lainnya yang terdapat di desa Hutauruk tersebut.

Kegiatan-kegiatan kelompok remaja gereja ini juga disambut baik oleh remaja dan juga masyarakat setempat, hal ini berarti kelompok remaja gereja memberikan dampak nyata bagi remaja maupun masyarakat setempat. Banyak orangtua yang kemudian ikut berpartisipsasi dengan mengikut sertakan anaknya dalam setiap kegiatan yang dilakukan remaja gereja. Karena mereka juga mengiginkan anak-anaknya memiliki lingkungan sosial yang sehat dan dapat terjauhkan dalam pergaulan bebas dan tindakan-tindakan kriminal lainnya.

Maraknya peredaran dan penyalahgunaan narkoba yang terjadi di desa ini membuat orangtua menjadi sangat khawatir. Orangtua khawatir dengan pergaulan dan lingkungan sosial di desa mereka dapat membuat anak-anak mereka terjerumus kedalam penyalahgunaan narkoba.

Untuk itu guna mencegah kelompok remaja ini masuk ke dalam peredaran negative dan penyalahgunaan narkoba maka perlu untuk mengisi waktu mereka dengan hal-hal yang positif dan bermanfaat. Salah satu kegiatan usaha yang disepakati untuk dilakukan adalah membuka usaha doorsmeer.

Peluang usaha cuci motor dan mobil bisa jadi adalah salah satu usaha yang relatif tidak beresiko tinggi. Apalagi dengan jumlah sepeda motor atau mobil seperti ini makin bertambah, ditambah cuaca yang sering berubah dan budaya orang-orang di sekitar kita, maka membuka bisnis jasa cuci motor dan mobil merupakan alternatif yang cukup menjanjikan.

\section{KESIMPULAN DAN SARAN}

\subsection{Kesimpulan}

1. Kegiatan pengabdian berlangsung dengan baik dan memperoleh sambutan yang besar dari mitra.

2. Terjadi perubahan perilaku mitra menjadi senang untuk beraktivitas yang sifatnya positif.

\subsection{Saran}

Hendaknya kegiatan pengabdian dan pendampingan kepada masyarakat dapat terus dilakukan dan jangkauan serta volumenya supaya lebih ditingkatkan agar keberadaan Universitas Sumatera Utara dapat lebih dirasakan oleh masyarakat luas. 
Vita Camellia et.al Empowerment of peer group

\section{UCAPAN TERIMAKASIH}

Tim pelaksana kegiatan pengabdian kepada masyarakat mengucapkan terima kasih kepada Lembaga Pengabdian Kepada Masyarakat USU yang telah mendanai kegiatan ini

\section{DAFTAR PUSTAKA}

Anwas, Oos M. 2013. Pemberdayaan Masyarakat di Era Global. Alfabeta. Bandung.

BNN. 2015. Mengenal Penyalahgunaan Narkoba. Badan Narkotika Nasional. Jakarta.

Gunarsa, Singgih. 2012. Psikologi Praktis: Anak, Remaja dan Keluarga. Gunung Mulia. Jakarta.

Murtadho, D 2013. Penanganan dan Pemberdayaan Masyarakat Miskin Kota. PT. Sarana Perkasa. Jakarta.

Rianse, Usman, 2014. Membangun Usaha Mikro dan Kecil: Menciptakan Ruang Bagi Kesejahteraan Masyarakat Urban. Unhalu Press. Kendari.

Robert, Alberts R; J. Greene Gilbert. 2012. Buku Pintar Pekerja Sosial Jilid I. BPK Gunung Mulia. Jakarta.

Sarwono, Wirawan. 2012. Psikologi Remaja. Raja Grafindo Perkasa. Jakarta.

Soegandhi, 2015. Pembangunan Masyarakat Urban. PT Raja Grafindo Persada. Jakarta. 